\title{
Using Some Fungicide-Alternatives to Control Septoria Leaf Spot of Celery and Improve its Yield.
}

\author{
Ghebrial, E.W.R ${ }^{1}$ and Kenawy, A.G.M. ${ }^{2}$ \\ 1-Plant Pathology Research Institute, ARC, Giza, Egypt. \\ 2-Horticulture Research Institute, ARC, Giza, Egypt.
}

\begin{abstract}
Aield experiments were carried out under natural infection of Septoria leaf spot in the Experimental Farm of Sids Agricultural Research Station, Agric. Res. Center, Beni-Sweif governorate in 2015/2016 and $2016 / 2017$ to evaluate the efficacy of hot water, organic acids, natural oils and bioagents on Septoria leaf spot and productivity of celery plants. Generally, all treatments were effective in reduction of disease severity. Also, a significant increase in fresh and dry weights of the herb, total chlorophyll as well as essential oil percent and oil yield was observed at the end of experiment. The use of the tested materials individually as seed treatments and foliar spray were less effective in reducing the disease incidence and severity than combined treatments with hot water-treated seeds and foliar spray with any of the tested materials. The highest efficacy was obtained from plots received hot water-treated celery fruits combined with phycare + thyme oil as a foliar spray in addition to the fungicide Ridomil gold MZ 68 WG. Furthermore, all the treatments showed significant increases in the defence-related enzymes, peroxidase (POD) and polyphenoloxidase (PPO) as compared with the untreated control.
\end{abstract}

Keywords: Septoria leaf spot, hot water, organic acids, natural oils, bioagents, defence-related enzymes, peroxidase, polyphenoloxidase, productivity and celery.

Celery (Apium graveolens L., Family Apiaceae) is an economically important annual herb crop cultivated mainly for medicinal purposes, food flavoring as well as for exportation. Celery gives significant amount of vitamins A and C, calcium, sodium and contains very little carbohydrate or fat, making it used as a diet food (Lacy et al., 1996).

Recently, a new serious disease affecting the cultivation of celery, Septoria blight, caused by Septoria apiicola Speg. was observed for the first time in Egypt in Beni-Sweif governorate in 2015. Since then, the disease has been quickly spread to all the Egyptian celery-growing areas, affecting yield, quality and causing losses of 50-90\% (Hilal and Ghebrial, 2015). Symptoms appear as irregularly shaped spots of necrotic tissue on leaves, petioles and seed coats, in which spore-containing pycnidia are immersed. The spots expand with time and coalesce leading to leaf death. The epidemiology of this disease depends on weather conditions, being favored by high moisture and temperature from 10 to $30^{\circ} \mathrm{C}$. Conidia within the pycnidia are surrounded by a mucilaginous matrix consists of proteins and sugars which swells when the mucilaginous matrix absorbs free 
water or is exposed to relative humidity higher than $90 \%$ (Lacy et al., 1996). Each pycnidium is capable of releasing 1500 to 5400 conidia. Germination of conidia was higher in the presence of free moisture and infection occurs when celery leaves remain wet for $\geq 12 \mathrm{~h}$ (Mathieu \& Kushalappa, 1993 and Lacy, 1994). The pathogen is transmitted with seed and it also overwinters on plant debris. Seed-borne diseases are considered high problem for successful production at the level of yield and its quality where seed can carry the pathogen which represents an important threat to crop yield, causing a reduction in germination, seedling damages, primary infection onset and species spreading (Riccioni and Orzali, 2011). So, effective seed treatments are needed to eradicate or at least to reduce the seed-borne inoculum. Seed treatment by fungicides remains the most effective means in this respect but this is difficult for medicinal and exportation crops like celery, due to the risk of the presence of residues at harvest besides health hazards and environmental pollution. Several non-chemical methods of seed treatment include physical treatments, seed treatments using organic acid, natural essential oil and bio-control agents offer an effective way to replace the use of synthetic fungicides (Mancini and Romanazzi, 2014). The successful result of a seed treatment depends not only on the effectiveness of the compound applied but also on the degree of internal infection of the seed, the amount of inoculum in seeds and the specificity and phytotoxicity of the treatment (Du Toit, 2004). Physical treatments consist of heat treatments of seeds with hot water that consists of the immersion of seeds in agitated water at a predetermined temperature and time. Thermotherapy inactivates or kills the pathogen, while it leaves the host tissue viable (Schmitt et al., 2009). Many essential oils have been found to contain natural antimicrobial compounds that varied in their toxicity against different fungal pathogens (Pina-Vaz et al., 2004 and Soylu et al., 2006). Biological control using antagonistic microorganisms investigated as a viable method in the protection of plants against Septoria sp. (Kashyap, 2013). However, the bio-control agents, Trichoderma spp. and Pseudomonas spp. can improve the growth of plants directly by increasing germination percentage, plant height, dry weight (Nzanza et al., 2011 and Elekhtyar, 2015) and/or indirectly by control of diseases (Harman et al., 2001 and Lucy et al., 2004). The essential oils and biocontrol agents can be used alone for seed disinfection or in combination with physical treatments (Begum et al., 2010). Organic acid such as citric acid, ascorbic acid can be a potential control agent against some plant pathogenic fungi (Haggag and Abd El-Khair, 2007). Organic acids are a source of both carbon and energy for cells and are used in the respiratory cycle and some other biochemical pathways (Darandeh and Hadavi, 2012). Foliar application of citric acid, ascorbic acid stimulated the growth, increasing productivity from the fresh herb, seeds and increased the essential oil content of sweet basil, dill, and thyme by enhancing photosynthesis and more tolerance to stress. (Jafari and Hadavi, 2012 a,b.; Miri et al., 2015 and Azoz et al., 2016). Therefore, this study aimed to evaluate the effectiveness of hot water, natural oils, organic acids and bio-control agents as seed treatments and foliar spray suspensions on Septoria blight of celery and its productivity under field conditions.

Egypt. J. Phytopathol., Vol. 46, No. 2 (2018) 


\section{Materials and Methods}

A two-year field experiment was achieved in Sids Experimental Farm of Agricultural Research Station, Agric. Res. Center, Beni-Sweif governorate in 2015/2016 and 2016/2017 to evaluate the efficacy of some treatments, physical method (hot water), organic acids, natural oils and bio-agents against Septoria leaf spot and productivity of celery. The soil of the experimental field was clay in texture $(16.5 \%$ sand, $30.1 \%$ silt, $53.4 \%$ clay), $\mathrm{pH}$ of 8.1 , EC $1.2 \mathrm{dSm}^{-1} ; 1.3 \%$ organic matter and 26.2, 10.1 and $176 \mathrm{ppm}$ available N, P, and K, respectively. Field experiments were conducted under natural infection in plots $(3 \times 3.5 \mathrm{~m})$ in a randomized complete block design with three replicates for each treatment.

During both experimental seasons, the following treatments were applied as seed treatment and foliar spray:

$\mathbf{T}_{1}$ : The commercial product Nimbecidine, containing neem oil $90.57 \%$ (obtained from Gaara Establishment for Import \& Export, Egypt) was applied as seed treatment and foliar spray at a rate of $0.6 \mathrm{~cm} / \mathrm{L}$ water.

$\mathbf{T}_{2}$ : $\quad$ Thyme oil (obtained from National Research Center, Egypt), applied as seed treatment and foliar spray at a rate of $1 \%$.

$\mathbf{T}_{3}$ : The commercial product Phycare, containing phosphorus $28 \% \mathrm{w} / \mathrm{w}$, citric acid, lactic acid, palmitic acid $25 \% \mathrm{w} / \mathrm{w}$ and ascorbic acid $0.625 \% \mathrm{w} / \mathrm{w}$ (obtained from Gaara Establishment for Import \& Export, Egypt), applied as seed treatment and foliar spray at a rate of $0.5 \mathrm{~cm} / \mathrm{L}$.

$\mathbf{T}_{4}$ : $\quad$ Pseudomonas fluorescens $\left(1 \times 10^{8} \mathrm{cfu}\right)$ was kindly obtained from Department of Microbiology, Soil and Water Res. Inst. and applied as seed treatment and foliar spray.

$\mathbf{T}_{5}$ : Trichoderma harzianum $\left(1 \times 10^{6}\right.$ conidia/ml $)$ was kindly obtained from Department of Microbiology, Soil and Water Res. Inst., applied as seed treatment and foliar spray.

$\mathbf{T}_{6}$ : Hot water at $47^{\circ} \mathrm{C}$ as a seed treatment.

$\mathbf{T}_{7}$ : Hot water as seed treatment and phycare + neem oil as a foliar spray.

$\mathbf{T}_{\mathbf{8}}$ : Hot water as seed treatment and phycare + thyme oil as a foliar spray.

$\mathbf{T}_{\mathbf{9}}$ : Hot water as seed treatment and phycare $+P$. fluorescens as a foliar spray.

$\mathbf{T}_{\mathbf{1 0}}$ : Hot water as seed treatment and phycare $+T$. harzianum as a foliar spray.

$\mathbf{T}_{11}$ : The fungicide Ridomil gold MZ 68 WG (Metalaxyl-M $4 \%+$ Mancozeb 64 $\%$ ) was applied as seed treatment and foliar spray at the rate of $50 \mathrm{gm} / 100 \mathrm{~L}$ water.

$\mathbf{T}_{12}$ : Control (untreated).

Celery fruits were soaked individually in the suspension of the tested treatments with continuous stirring for $4 \mathrm{~h}$. before sowing. A few drops of the emulsifier Tween 20 were added to the thyme oil to obtain an emulsion feature. The fruits were placed in emulsion (usually in $100 \mathrm{ml}$ beaker), plugged and continue stirring for $4 \mathrm{~h}$. T. 
harzianum was grown in Trichoderma-selective medium broth (TSM) (Elad et al., 1981), amended with $300 \mathrm{mg} / 1$ streptomycin and $50 \mu \mathrm{g} \mathrm{ml}^{-1}$ rose Bengal in a conical flask, incubated at $25^{\circ} \mathrm{C}$ for 15 days. P. fluorescens was multiplied in King B (KB) liquid medium for $48 \mathrm{~h}$ at $28 \pm 2^{\circ} \mathrm{C}$ on a shaker (King et al., 1954). Celery fruits were soaked in the suspension of Trichoderma isolate $\left(1 \times 10^{6}\right.$ conidia/ml $)$ and $P$. fluorescens $\left(1 \times 10^{8} \mathrm{cfu}\right)$ for $4 \mathrm{~h}$ before sowing. For hot water treatment, celery fruits were wrapped loosely in a woven cotton bag (such as cheesecloth) and pre-warmed in the water at $37^{\circ} \mathrm{C}$ for ten minutes then placed in a water bath at $47^{\circ} \mathrm{C}$ for 30 minutes (Miller and Lewis Ivey, 2005). After treatment, the fruits were cooled under cold tap water $\left(10^{\circ} \mathrm{C}\right)$ for 5 minutes to stop the heating action and then dried at room temperature (Lewis Ivey $\&$ Miller, 2005). Celery fruits were soaked in water served as control. Germination tests were performed according to ISTA rules (Anonymous, 2000) using seeds placed on moist filter paper as described by (Schmitt et al., 2009). The percentage of germinated fruits was recorded after 21 days.

In each season, the soil was mechanically plowed and planked twice. During the preparation for cultivation, calcium super-phosphate $\left(15.5 \% \mathrm{P}_{2} \mathrm{O}_{5}\right)$ as a source of phosphorus was added at the rate of $200 \mathrm{~kg} / \mathrm{fed}$. The treated and untreated celery fruits were sown in the field at the rate of $6-8 \mathrm{~kg} / \mathrm{fed}$ on October, $15^{\text {th }}$ in the two experimental seasons. Weeds were removed by manual operations as needed and plants were irrigated regularly as necessary, throughout the growing season to maintain constant growth. Nitrogen was applied in the form of ammonium sulfate $(20.6 \% \mathrm{~N})$, at the rate of 400 $\mathrm{kg} / \mathrm{fed}$. (recommended rate) as follow: the first one $(100 \mathrm{~kg} / \mathrm{fed}$.) was added after 21 days from sowing fruits and the second amount (100 kg/fed.) was added after 15 days from the first application. The remainder amounts were added after each cut. Potassium sulfate $\left(48 \% \mathrm{~K}_{2} \mathrm{O}\right)$ as a source of potassium at the rate of $100 \mathrm{~kg} / \mathrm{fed}$. was used two times. The first one was applied with the second amount of nitrogen application and the second one after the $1^{\text {st }}$ plant cut. The plants were sprayed weekly, always performed early in the morning, with the tested compounds, $1 \%$ Tween 20 before the appearance of first symptoms until run off. Monitoring and scouting the plants weekly for the appearance of leaf spot and disease incidence and severity were estimated as follow:

\section{Disease incidence:}

Percentage of disease incidence was recorded and efficiency was calculated using the formula:

$$
\text { Efficiency } \%=\frac{[\mathrm{C}-\mathrm{T}]}{\mathrm{C}} \times 100
$$

Whereas: $\mathrm{C}$ and $\mathrm{T}$ are the percentage of Septoria leaf spot incidence in control and treated plants, respectively.

\section{Disease severity:}

Disease severity was measured according to (Yan et al., 2002). Percentage of disease severity was recorded according to the following equation: 


$$
\text { Disease severity } \%=\frac{\left[\sum(\mathrm{n} \mathrm{x} \mathrm{c})\right]}{(\mathrm{N} \times \mathrm{C})} \times 100
$$

Whereas: $\mathrm{n}=$ Number of infected leaves, $\mathrm{c}=$ Category number, $\mathrm{N}=$ Total number of examined leaves and $\mathrm{C}=$ the highest category number of infection.

The plants were harvested three times in each growing season. The first cut was done on $1^{\text {st }}$ January, the second and third ones were done every 45 days by cutting the vegetative parts of the plants $10 \mathrm{~cm}$ above the soil surface with three replications in each cut. Fresh and dry weights of herb yield (ton/fed.) were determined.

Total chlorophyll (mg/g fresh weight) was determined at harvesting herb of celery fresh leaves samples using the method by Moran (1982).

To determine the percentage of essential oil, the fresh herbs were collected from each treatment during the three cuts. They were dried by air and weighted (100g dry herb/treatment) representing each replicate then subjected to steam distillation and determined according to Guenther (1961) and oil yield (kg/ fed.) was determined.

Peroxidase activity was determined using the method described in the Worthington enzyme manual (Worthington, 1971). Polyphenoloxidase activity was measured following the method described by (Esterbaner et al., 1977). Analysis of enzymes was carried out at the Central Lab. for Biotechnol., Plant Pathol. Res. Inst., ARC.

Data were statistically analyzed for computing L.S.D. test at $5 \%$ probability according to the procedure outlined by Snedecor and Cochran (1989).

\section{Results}

The field experimental data revealed that the tested treatments applied alone or in combination have the potential to reduce the incidence of the Septoria induced disease on celery (Table, 1 ). In the $1^{\text {st }}$ growing season, $\mathrm{T}_{11}$ (Ridomil gold MZ $68 \mathrm{WG}$ ) was the most efficient in this regard which significantly reduced the number of leaf spots and disease incidence with efficiency $89.4,83.7$ and $85.4 \%$, respectively for the first, second and third plant cuts followed by $\mathrm{T}_{8}$ (hot water-treated seeds combined with phycare + thyme oil as foliar spray) which statistically at par with the fungicide treatment. The efficiency of this treatment in reducing the disease was 87.0, 78.5 and $81.8 \%$, respectively. $\mathrm{T}_{7}$ (hot water-treated seeds combined with phycare + nimbecidine as foliar spray) came in the second rank with efficiency reached 78.9, 69.7 and $74.1 \%$ followed by $\mathrm{T}_{9}$ (hot water-treated seeds combined with phycare $+P$. fluorescens as foliar spray). Meanwhile, $\mathrm{T}_{10}$ (hot water-treated seeds combined with phycare $+T$. harzianum as foliar spray) showed the lowest efficiency in the combined treatments. However, the use of the tested materials individually as seed treatments and foliar spray were less effective in reducing the disease incidence than combined treatments with hot water-treated seeds and foliar spray with any of the tested materials. In this respect, $T_{3}$ 
(the commercial product phycare) was the most effective in individual treatments which reduced disease incidence by $60.3,49.1$ and $53.4 \%$ for the three plant cuts, respectively. The essential thyme oil as seed treatment and foliar spray $\left(\mathrm{T}_{2}\right)$ did not differ significantly with the phycare treatment $\left(\mathrm{T}_{3}\right)$ which was effective in reducing the numbers of leaf spots than nimbecidine $\left(\mathrm{T}_{1}\right)$. The efficiency of thyme oil treatment was 57.6, 45.9 and $50.5 \%$, respectively for the three plant cuts. Meanwhile, the application of $P$. fluorescens as seed treatment and foliar spray $\left(\mathrm{T}_{4}\right)$ was more effective than the bioagent $T$. harzianum treatment $\left(\mathrm{T}_{5}\right) . \mathrm{T}_{6}$ (Hot water treatment) was the lowest efficient in controlling Septoria leaf blight. The same trend was observed in the $2^{\text {nd }}$ growing season.

Table 1: Efficiency percentage of different treatments against Septoria leaf spot through the three celery plant cuts during 2015/2016 and 2016/2017 successive growing seasons.

\begin{tabular}{|c|c|c|c|c|c|c|}
\hline \multirow{3}{*}{ Treatments } & \multicolumn{6}{|c|}{ Efficiency (\%) of different treatments on disease incidence } \\
\hline & \multicolumn{3}{|c|}{$1^{\text {st }}$ Season $(2015 / 2016)$} & \multicolumn{3}{|c|}{$2^{\text {nd }}$ Season $(2016 / 2017)$} \\
\hline & $1^{\text {st }}$ cut & $2^{\text {nd }}$ cut & $3^{\text {rd }}$ cut & $1^{\text {st }} \mathrm{cut}$ & $2^{\text {nd }}$ cut & $3^{\text {rd }} \mathrm{cut}$ \\
\hline $\mathrm{T}_{1}$ & 52.4 & 38.7 & 45.0 & 54.0 & 37.1 & 46.8 \\
\hline $\mathrm{T}_{2}$ & 57.6 & 45.9 & 50.5 & 60.3 & 47.3 & 51.4 \\
\hline $\mathrm{T}_{3}$ & 60.3 & 49.1 & 53.4 & 64.6 & 50.8 & 55.6 \\
\hline $\mathrm{T}_{4}$ & 46.9 & 30.3 & 37.0 & 46.2 & 33.6 & 39.3 \\
\hline $\mathrm{T}_{5}$ & 34.5 & 22.2 & 27.9 & 37.6 & 24.6 & 27.5 \\
\hline $\mathrm{T}_{6}$ & 32.9 & 17.0 & 22.6 & 33.0 & 20.5 & 25.3 \\
\hline $\mathrm{T}_{7}$ & 78.9 & 69.7 & 74.1 & 81.0 & 68.4 & 76.4 \\
\hline $\mathrm{T}_{8}$ & 87.0 & 78.5 & 81.8 & 89.4 & 79.3 & 84.2 \\
\hline $\mathrm{T}_{9}$ & 71.7 & 58.3 & 64.5 & 73.2 & 60.5 & 66.4 \\
\hline $\mathrm{T}_{10}$ & 65.0 & 52.4 & 57.8 & 65.9 & 51.7 & 58.0 \\
\hline $\mathrm{T}_{11}$ & 89.4 & 83.7 & 85.4 & 92.0 & 82.6 & 87.1 \\
\hline $\mathrm{T}_{12}$ & 0.0 & 0.0 & 0.0 & 0.0 & 0.0 & 0.0 \\
\hline L.S.D ${ }_{0.05}$ & 5.1 & 5.6 & 4.9 & 5.7 & 3.4 & 4.5 \\
\hline
\end{tabular}

Results in Figures, 1 and 2 indicate that there were significant differences in severity of Septoria leaf blight among the treatments tested compared with the untreated control. In the $1^{\text {st }}$ growing season, disease severity was higher in plots received the treatments individually than plots received combined treatments. The most effective treatments were $\mathrm{T}_{11}\left(8.0,17.8\right.$ and $12.4 \%$, respectively for the three plant cuts) followed by $\mathrm{T}_{8}$ $(10.9,20.2$ and $15.0 \%$, respectively) without any significant differences between them. Moderate effects were shown with $\mathrm{T}_{9}$ followed by $\mathrm{T}_{10}$ treatment. From individual 
treatments, $T_{3}$ significantly reduced disease severity to an important level followed by $\mathrm{T}_{2}$ with no significant differences between them. The corresponding mean values were $25.6,35.7 \& 31.8$ and $27.6,38.6 \& 33.9 \%$, respectively. The bioagent $P$. fluorescens $\left(\mathrm{T}_{4}\right)$ was significantly more effective in reducing severity and number of leaf spots than $T$. harzianum treatment $\left(\mathrm{T}_{5}\right)$. Meanwhile, treated celery seeds with hot water $\left(\mathrm{T}_{6}\right)$ only showed the least effective in this concern. The same trend was observed in the $2^{\text {nd }}$ growing season.

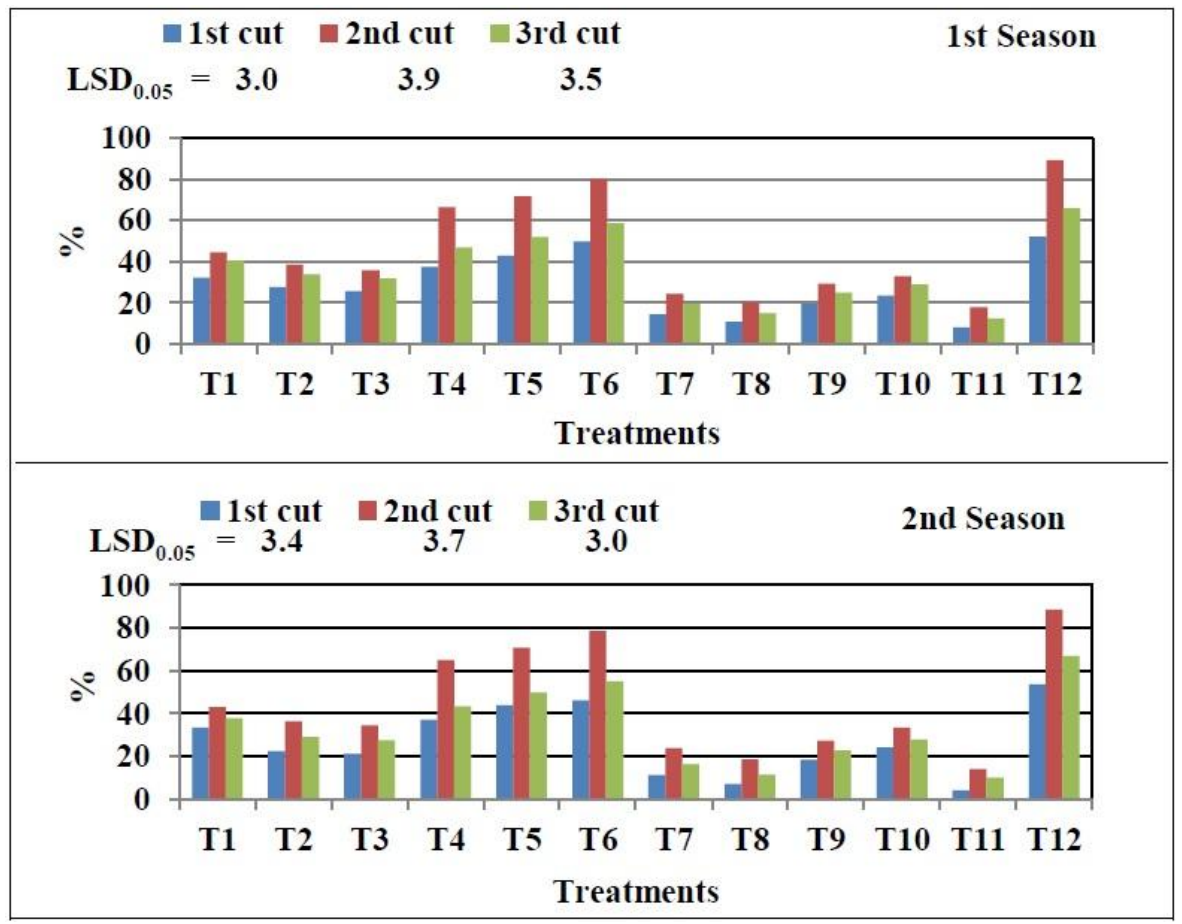

Figure 1: Effect of different treatments on severity of Septoria leaf spot through the three celery plant cuts during two successive growing seasons (2015/2016 and 2016/2017).

All the tested treatments had no negative effect on the germination of celery seeds (Table, 2). No significant differences among the means of various treatments, control, essential oils, the commercial product phycare, bio-agents, and hot water were detected. Nimbecidine, thyme oil, phycare, T. harzianum, and $P$. fluorescens-treated seeds showed the same germination level $(100 \%)$ as control seeds in the two seasons. Seedstreated with hot water at $47^{\circ} \mathrm{C}$ for $30 \mathrm{~min}$. had no significant effect on germination (98 and $97 \%)$ compared to the control (100\%) in the two seasons, respectively. 


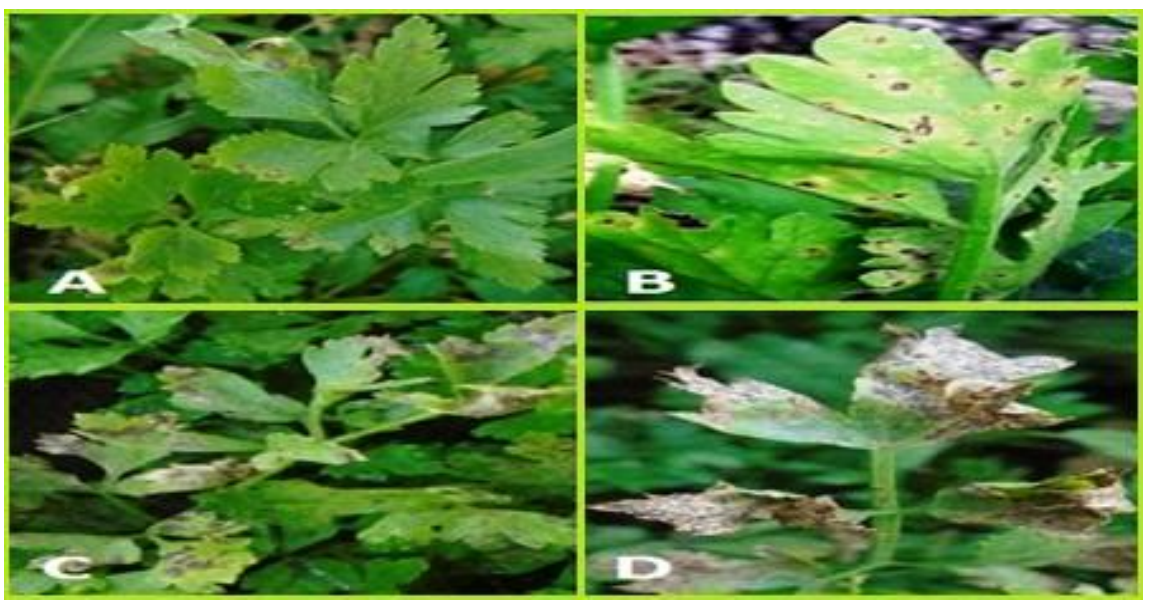

Figure 2: Effect of hot water-treated seeds combined with phycare + thyme oil as foliar spray treatment (A); Phycare (B) and hot water treatment (C) on severity of septoria leaf spot of celery compared with the untreated control (D).

Table 2: Effect of different treatments on celery seed germination

\begin{tabular}{|c|c|c|}
\hline \multirow{2}{*}{ Treatments } & \multicolumn{2}{|c|}{ Germination percent } \\
\hline & $1^{\text {st }}$ Season & $2^{\text {nd }}$ Season \\
\hline Nimbecidine & 100 & 100 \\
\hline Thyme oil & 100 & 100 \\
\hline Phycare & 100 & 100 \\
\hline P. fluorescens & 100 & 100 \\
\hline T. harzianum & 100 & 100 \\
\hline Hot water & 98 & 97 \\
\hline Ridomil gold MZ 68 WG & 100 & 100 \\
\hline Control & 100 & 100 \\
\hline L.S.D 0.05 & ns & ns \\
\hline
\end{tabular}

All treatments increased the proportion of healthy celery plants and did not show any signs of phytotoxicity. As seen in Figures, 3 and 4 there were significant differences among the treatments in terms of the fresh and dry weights of celery plants compared with the untreated control. The highest weights were observed with $\mathrm{T}_{11}$ (Ridomil gold MZ $68 \mathrm{WG}$ ) treatment, being 3.96, $5.64 \& 4.90$ ton/fed., respectively, for the three plant cuts in fresh weight and dry weight, being $0.75,1.07 \& 0.93$ ton/fed., respectively, followed by $\mathrm{T}_{8}$ with no significant differences between them which gave $3.85,5.47 \&$ 4.87 ton/fed., and $0.73,1.03 \& 0.95$ ton/fed., respectively for the three plant cuts during the $1^{\text {st }}$ season. $T_{7}$ gave also best results followed by $T_{9}$ treatment. A single treatment of 
phycare $\left(T_{3}\right)$ followed by thyme oil treatment $\left(T_{2}\right)$ showed a moderate increase. The lowest fresh and dry weights were recorded with $\mathrm{T}_{6}$. The same trend was observed in the ${ }^{2 \text { nd }}$ growing season.

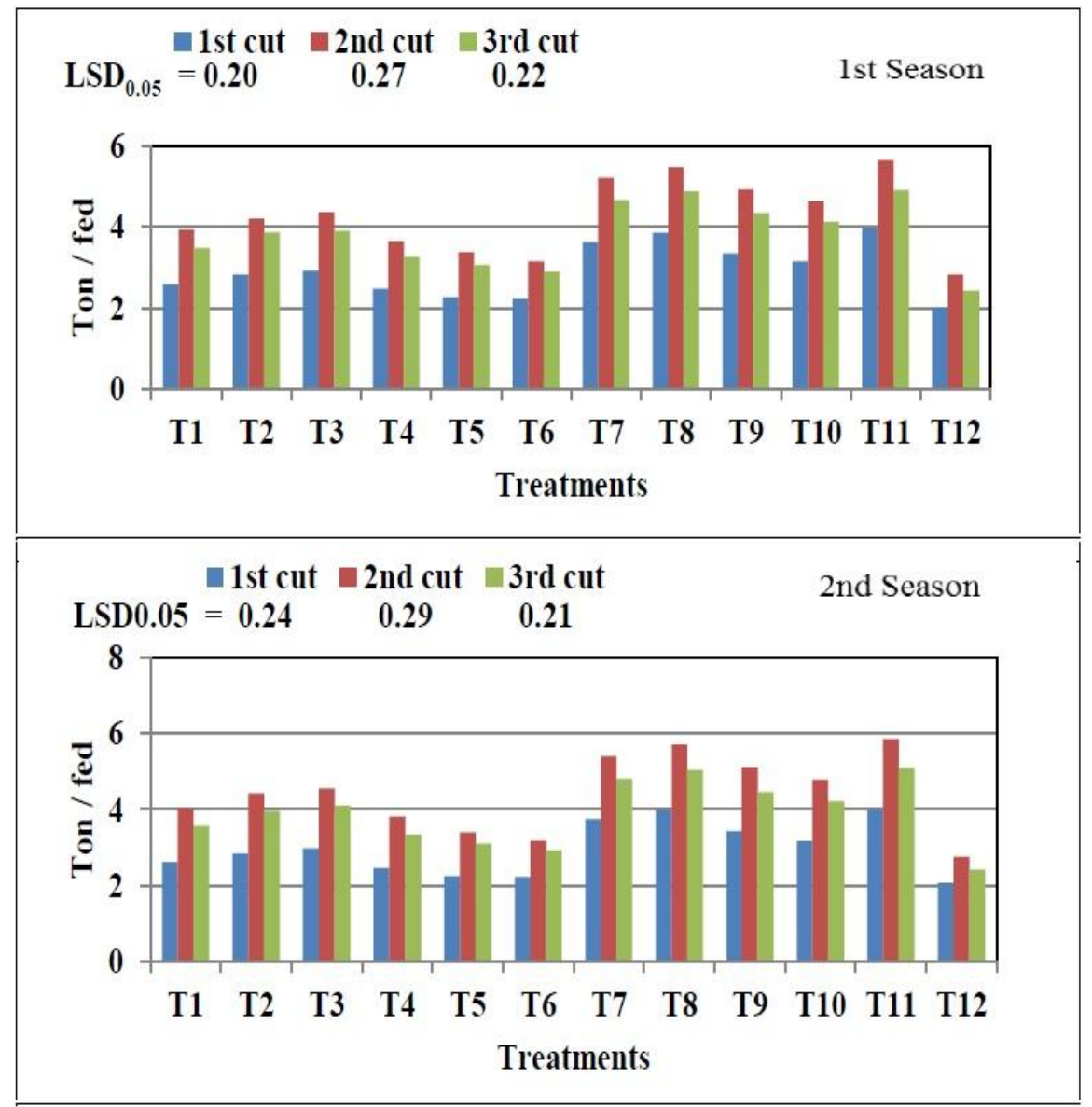

Figure 3: Effect of different treatments on fresh weight (ton/fed.) through the three celery plant cuts during two successive growing seasons $(2015 / 2016$ and 2016/2017). 


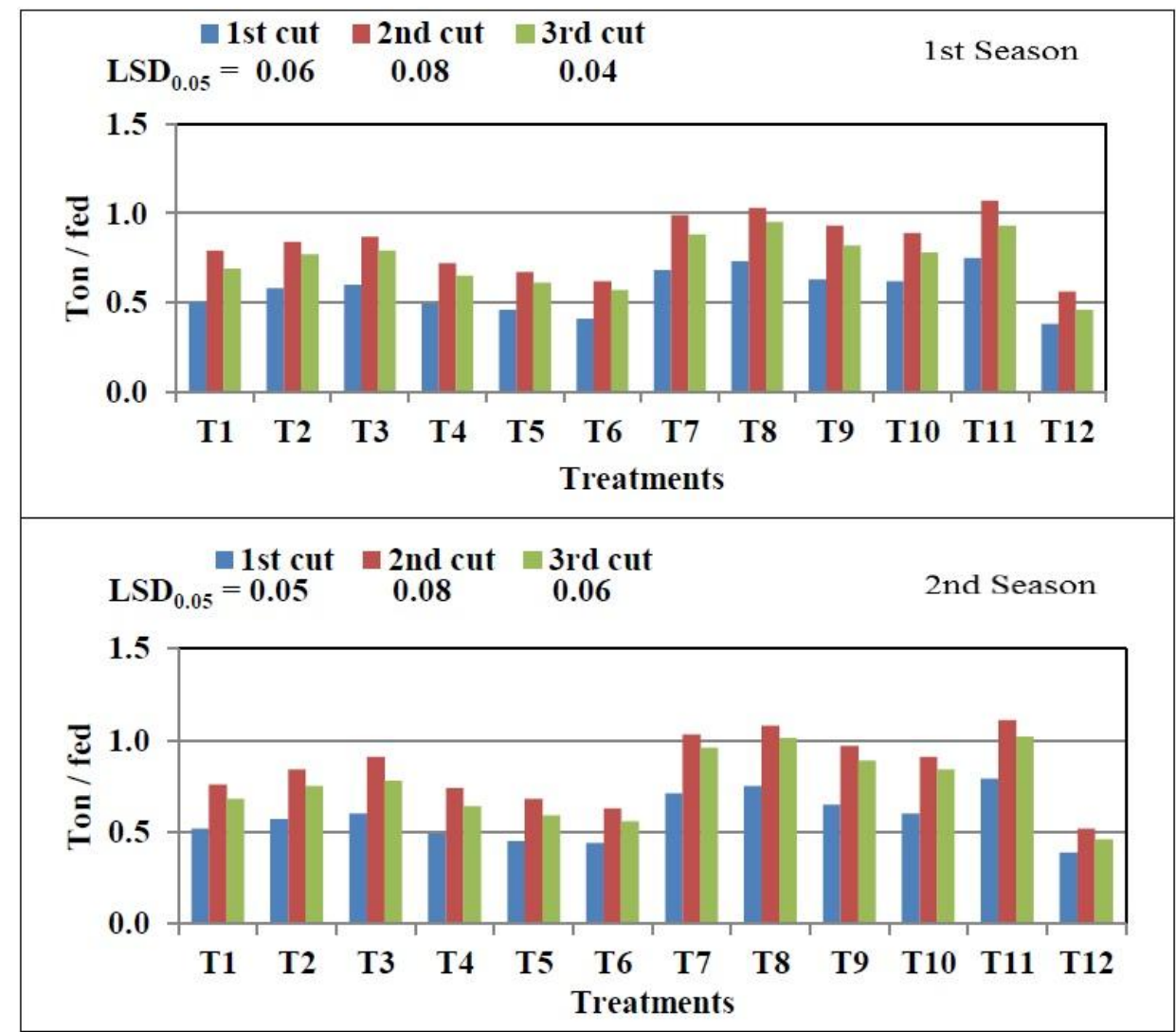

Figure 4: Effect of different treatments on dry weight (ton/fed.) through the three celery plant cuts during two successive growing seasons (2015/2016 and 2016/2017).

It seems that all the treatments significantly increased the chlorophyll content compared with the untreated control (Figure, 5 ). In the $1^{\text {st }}$ growing season, $\mathrm{T}_{8}$ treatment had a profound effect on the total chlorophyll by collapsing the spots on the leaf surface which gave the highest chlorophyll content $(10.19,9.54$ and $9.46 \mathrm{mg} / \mathrm{g}$ fresh weight), respectively for the three plant cuts followed by $\mathrm{T}_{7}$ treatment which was statistically at bar with the $T_{11}$ treatment. In general, the combined treatments showed more chlorophyll content than the single treatments. The least total chlorophyll content (8.61, 8.30 and $8.20 \mathrm{mg} /$ g F.W.) was observed with $\mathrm{T}_{6}$ which statistically showed no significant differences with control treatment (8.36, 8.00 and $7.69 \mathrm{mg} / \mathrm{g}$ F.W.), 
respectively for the three plant cuts. The same trend was observed in the $2^{\text {nd }}$ growing season.

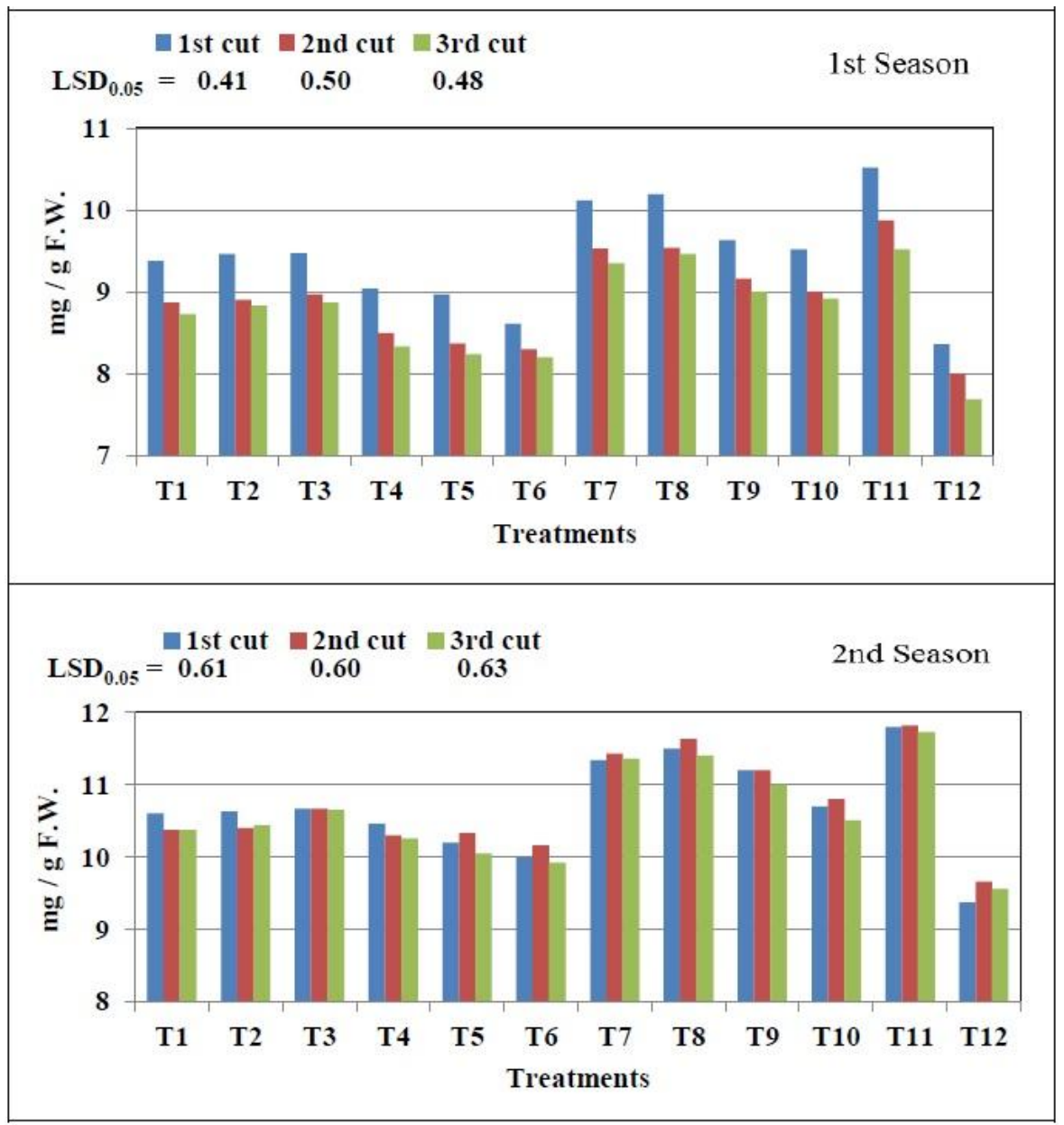

Figure 5: Effect of different treatments on total chlorophyll $(\mathrm{mg} / \mathrm{g}$ fresh weight) through the three celery plant cuts during two successive growing seasons (2015/2016 and 2016/2017).

Data presented in Figures, 6 and 7 clearly show that all the treatments tested in single or in combination induced a significant increase in oil percent and oil yield over the untreated control. The maximum significant increase in oil $\%$ was detected with $\mathrm{T}_{8}$, 
being $0.63,0.65 \& 0.67 \%$ and $4.60,6.69 \& 6.36 \mathrm{~kg} / \mathrm{fed}$. in oil yield, respectively for the three plant cuts which showed no significant differences with $\mathrm{T}_{11} . \mathrm{T}_{7}$ came in the second rank followed by $T_{9}$. In general, the combined treatments were more effective in this respect than single treatments. At the same time, the use of hot water only as seed treatment $\left(\mathrm{T}_{6}\right)$ showed no significant effect with the untreated plants in this respect which gave the lowest oil \% and yield compared with the other treatments.

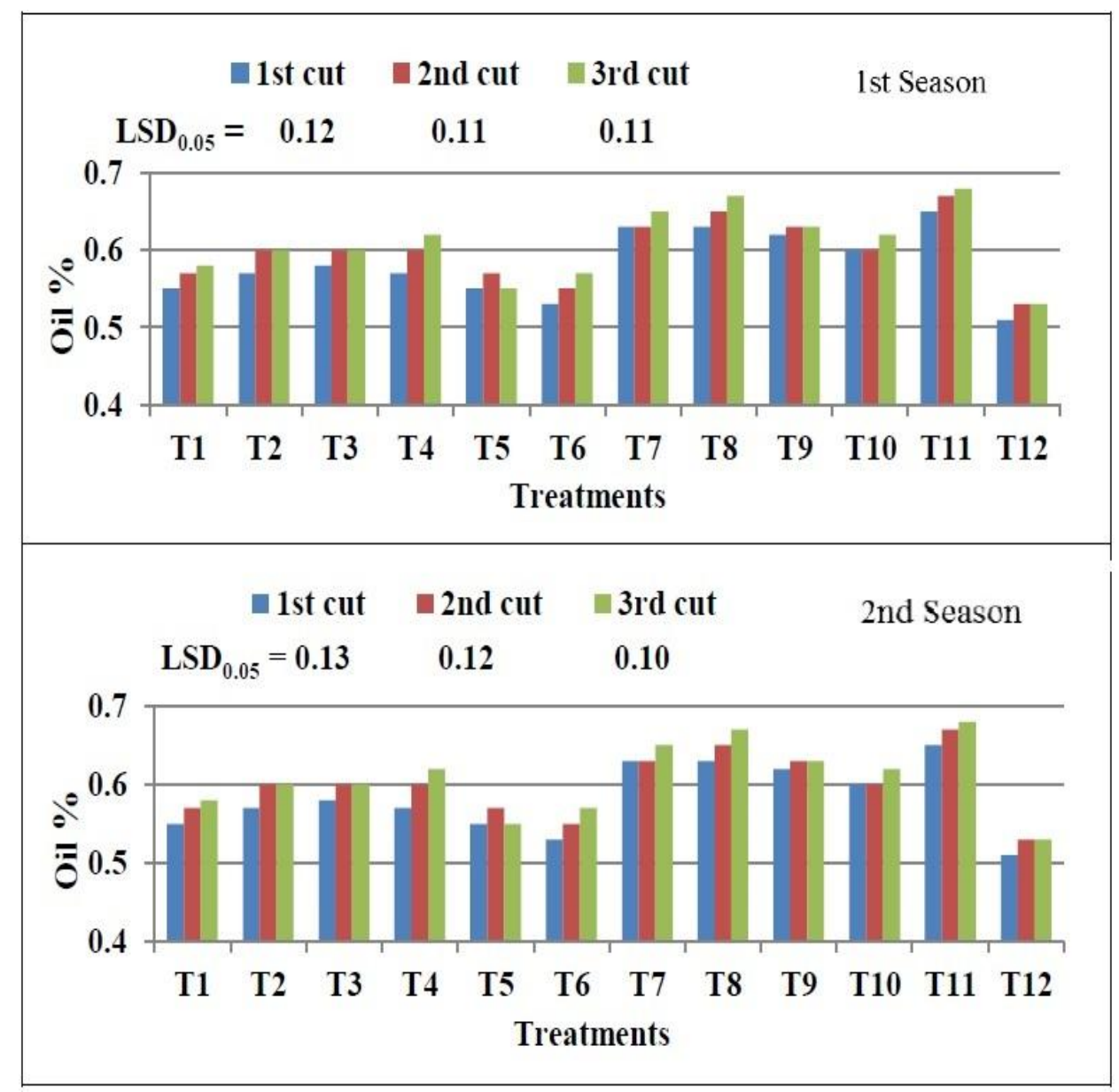

Figure 6: Effect of different treatments on oil percentage in the three celery plant cuts during two successive growing seasons (2015/2016 and 2016/2017).

Egypt. J. Phytopathol., Vol. 46, No. 2 (2018) 


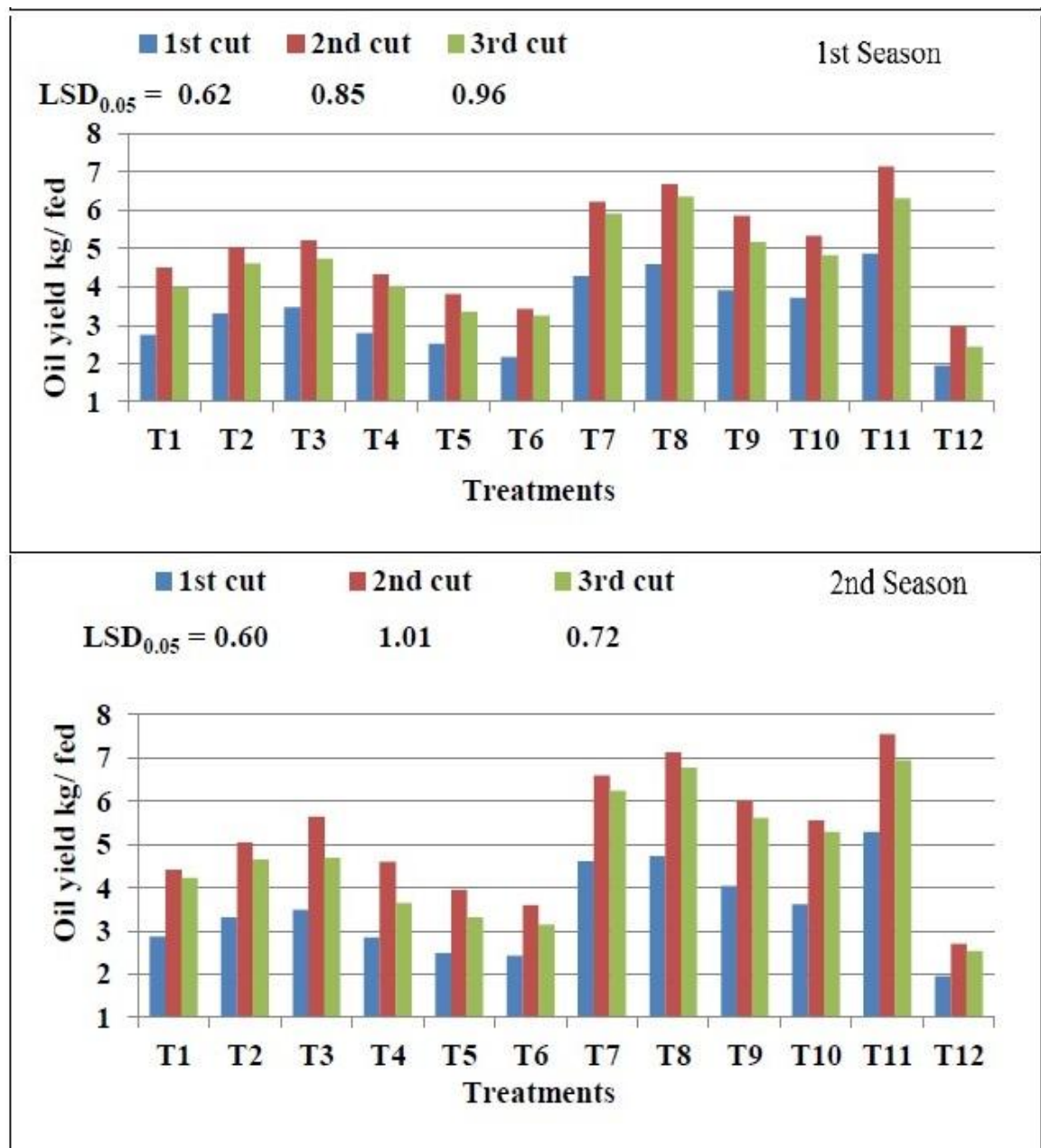

Figure 7. Effect of different treatments on oil yield $(\mathrm{kg} / \mathrm{fed}$.) through the three celery plant cuts during two successive growing seasons (2015/2016 and 2016/2017).

Results in Figure, 8 demonstrate that all treatments increased the peroxidase and polyphenoloxidase activities in celery plants. The highest activity was obtained with $\mathrm{T}_{8}$ and $\mathrm{T}_{7}$ which achieved 0.979 and $0.947 \mathrm{Umg}^{-1}$ in peroxidase enzyme and 0.458 and $0.424 \mathrm{Umg}^{-1}$ in polyphenoloxidase enzyme, respectively. Meanwhile, single treatment of hot water $\left(\mathrm{T}_{6}\right)$ was less effective. 


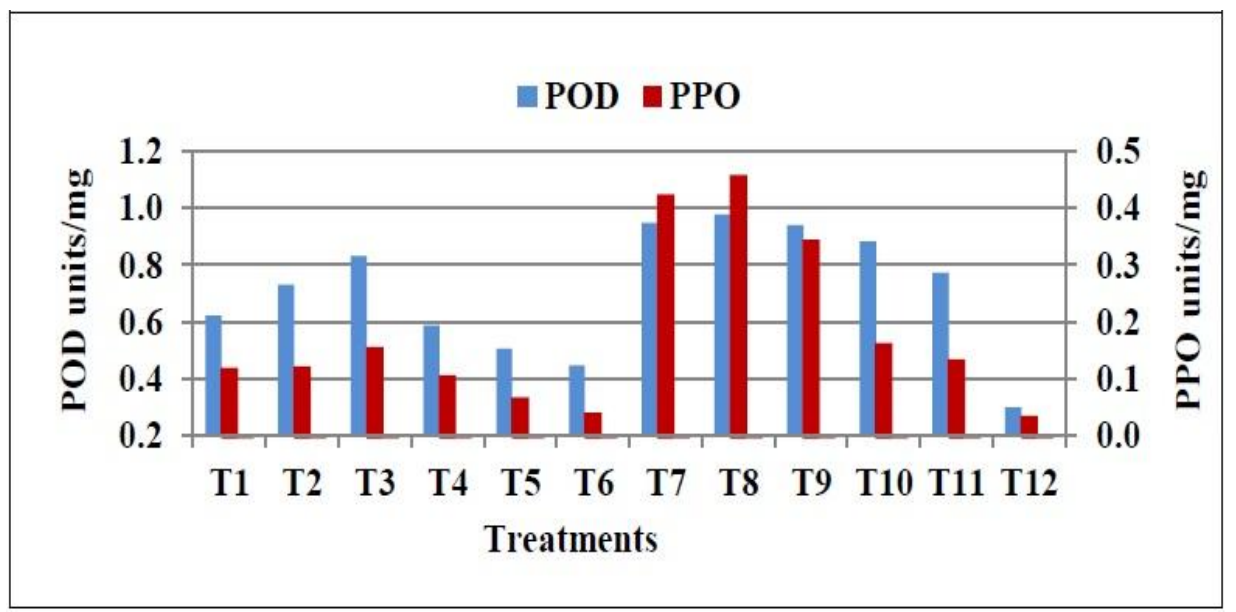

Figure 8. Enzyme activities in celery plants as affected by different treatments. $\mathrm{POD}=$ Peroxidase $; \mathrm{PPO}=$ Polyphenoloxidase

\section{D i s c u s s i o n}

Organic acids, natural oils, bio-control agents and hot water treatment can be applied successfully in plant production by enhancing natural resistance against plant diseases and as a plant growth stimulant (Amein et al., 2011). In the present study, it is worthy to note that all the tested treatments applied as seed treatment and foliar spray significantly reduced losses caused by Septoria leaf spot on celery plants and increased its productivity. The use of combined treatments increased the efficiency of the treatments and enhanced the suppressive effect against septoria blight. Hot water-treated seeds combined with phycare + thyme oil as foliar spray was the most effective treatment. It reduced disease incidence and severity to an acceptable level, increased fresh and dry weight, oil percent, oil yield and chlorophyll content as well as peroxidase, polyphenoloxidase activities of celery plants. Thyme oil contains p-cymene (36.5\%), thymol (33.0\%) and 1.8 cineole $(11.3 \%)$ as a main components (Segvić Klarić et al., 2007) which possess a wide range spectrum of fungicidal activity against seedborne and air-borne fungi when used as seed treatments and/or foliar spray (Schmitt $e t$ al., 2009 and Amein et al., 2011) and significantly increased crop yield under field conditions (El-Mohamedy and Abd-El-latif, 2015). El-Mougy (2009) demonstrated that the application of thyme essential oil as foliar spray proved to be highly effective treatments inducing increases of potato tuber yield by improving plant health. Thymol affects the surface electrostatics of the cell membrane and membrane integrity (Sánchez et al., 2004), as well as, damaging the cell wall, cell membrane and cellular organelles (Rasooli and Owlia, 2005). Neem plants contain several compounds of terpenoids that present in all parts of the plant from which Azadirachtin is the most active compound as 
antifungal, hormonal and increase nutrient efficiency by which the crop yield is enhanced when used as seed treatment and manorial application (Lokanadhan et al., 2012). Nahak and Sahu (2015) reported that spray of neem extract on tomato plants effectively control early blight and leaf spot and increased fruits of tomato plant in comparison to controls under field condition. Neem oil provided control of many fungal diseases through metabolic changes in plants including induction of phenol, antioxidant defensive enzymes and phenol accumulation (Abbasi et al., 2003). However, the promotive effect could be due to triterpene which acts by delaying the transformation of ammonium nitrogen into nitrate nitrogen (Akhtar, 1999). The volatile phases of the essential oils like thyme oil were found to be more toxic than the contact phase against plant pathogenic fungi (Inouye et al., 2000). They suggested that the antifungal activity resulted from a direct effect of essential oil vapors on fungal mycelium and concluded that the lipophilic nature of oil components was as possible for them being absorbed by fungal mycelia and aided in the ability of the oil to penetrate the plasma membrane.

Treatment of celery fruits with hot water at $47^{\circ} \mathrm{C}$ for $30 \mathrm{~min}$. can reduce contamination of seed by Septoria with the little negative effect on germination. This may be because the fungus was not found in seed embryos or endosperm but its mycelium was present in pericarps and testas (Sheridan, 1966). This result is closely in agreement with that reported by Muniz (2001) who reported that seed treatment with hot water reduced seed-borne pathogens such as fungi, bacteria even viruses of tomato. The possible postulated of decreasing the seed-borne pathogen may be due to hot water treatment, firstly the temperature acted upon the fungal contaminants and with increasing the temperature it penetrated within the seed and killed pathogen embedded in the seeds. Farahani and Chaichi (2012) showed that hot water treatment increased germination speed regardless of germination percentage; it can help earlier germination than weed. They added that to reduce the negative effect of hot water on germination, it is useful to induce water stress in the field to promote germination after hot water treatment. Mtui et al. (2010) reported that seeds of tomato treated with hot water gave higher fruit yields and lower severity of sunscald than plants from Ridomil treated seeds which were similar to control. This may be due to the higher vigor of plants from hot water treated seeds, which led to a denser canopy thereby providing better fruit protection from the sun.

The application of organic acids had the potential to protect plants against pathogens by inducing the plant to acquire systemic resistance to pathogens and induced favorable changes in anatomical structures of vegetative organs and consequently promotes vegetative growth and productivity. Khan et al. (2011) concluded that ascorbic acid enhances the tolerance of plant and regulate response to pathogenic stress as a result of a complex sequence of biochemical reactions such as activation or suppression of key enzymatic reactions, induction of stress-responsive proteins synthesis, and the production of various chemical defense compounds. Azoz et al. (2016) showed that foliar application of ascorbic acid at $300 \mathrm{ppm}$ increased stem diameter of basil plants by 
increasing thickness of the cortex, fiber strands, phloem tissue, and xylem tissue and decreased pith diameter as well as resulted in thicker leaves due to increase induced in thickness of both midvein and lamina. The thicker lamina induced by ascorbic acid treatment was mainly due to the prominent increase observed in the thickness of both palisade and spongy tissues. Wassel et al. (2007) assumed that the effect of ascorbic acid on the plant growth might be due to the auxinic action of ascorbic acid as well as, its improved role in many metabolic and physiological processes and enhancing the synthesis of carbohydrates. Omer (1999) reported that the increments of leaf area, leaf fresh and dry weight are due to ascorbic acid treatment which may be attributed to its effect on cell division and cell elongation. Maksoud et al. (2009) mentioned that increasing leaf dry weight might be due to the accumulation of dry matter production in the canopy, which can be assumed proportional to the solar radiation intercepted by foliage resulting in more efficiency of the photosynthesis process. Besides, El-Sayed (2013) reported that soaked tomato seeds in ascorbic acid at 50 ppm before planting leads to significant increase in the contents of chlorophyll a, b and in carotenoids as compared with the control plants. Increasing plant pigments chlorophyll \% may be due to the role of ascorbic acid in increasing the rates of photochemical reduction. Ismaeil and Bakry (2005) noticed that treating papaya plants with citric acid at $2 \mathrm{~g} / \mathrm{l}$ increased the thickness of epidermis, cortex, phloem zone and xylem zone in petiole flower. These findings refer to the possible increase of plants' resistance to fungal infection by spraying of certain organic acids such as ascorbic and citric acid through increasing the epidermis thickness as a mechanical barrier. Citric acid is one of the mobile forms of iron in plants, thus it plays an important role in iron transport (Darandeh and Hadavi, 2012). Jafari and Hadavi (2012b) assumed that citric acid alters the hydrocarbon partitioning towards pathways that are more related to resistance to pathogens, unfavorable conditions and secondary metabolism. They speculated that the application of citric acid as foliar spray increased proton pumping capabilities of roots, improving their organic acid efflux. This had, in turn, improved the overall ion absorption (especially $\mathrm{P}$ and $\mathrm{N}$ ) by plants and this finally led to increased performances and yields. The enhancement effect of citric acid, ascorbic acid on vegetative growth, essential oils was also recorded on other medicinal and aromatic plants (Reda et al., 2007, Khalil et al., 2010 and Soltani et al., 2014). Polymers of L-lactic acid increased plant biomass through increase chlorophyll accumulation and root growth. Promotion of chlorophyll accumulation and biomass may be due to increased ability to assimilate nutrients (Kinnersley, et al., 1990). Ascorbic acid plays multiple roles in plant growth, functioning in cell division, cell wall expansion, and other developmental processes (Conklin, 2001).

Seed treatment and foliar spray with $T$. harzianum and $P$. fluorescens can effectively control Septoria blight of celery and increased seedling emergence, fresh and dry weight, oil percentage, oil yield and total chlorophyll. This result is in agreement with the study by Amein et al. (2011) who worked with broccoli seeds and cabbage seeds. 
Pseudomonas spp. affect plant growth directly by producing and releasing secondary metabolites (plant growth regulators, phytohormones and biologically active substances), facilitating the availability and uptake of certain nutrients from the root environment and indirectly by inhibiting plant pathogenic organisms as a result of production of inhibitory substances or increasing the natural resistance of the host (Kaushal et al., 2013). However, Amutharaj et al. (2013) found that the favorable effect of $P$. fluorescens might be due to its stimulating effect for rapid growth or early seedling growth resulted in more cell division and elongation due to a secretion of indole acetic acid (IAA), abscisic acid (ABA) by bacteria leading to longest shoot because of the capability of bacteria for fixing nitrogen from air and enhanced metabolism process resulted in more energy and growth improvement. Pseudomonades produce cytokinins and gibberellins (gibberellic acid). Trichoderma, in association with plant roots, can trigger systemic resistance and improve plant nutrient uptake. Several strains of Trichoderma effectively affect the seed-borne phase of Fusarium head blight (FHB) or Scab in wheat when used as seed treatments (Xue et al., 2017). However, Yadav et al. (2015) showed that foliar application and seed coating of Trichoderma harzianum significantly reduced the incidence and severity of the spot blotch disease (Bipolaris sorokiniana) and leaf rust (Puccinia triticina) (El-Sharkawy et al., 2015). Furthermore, Contreras-Cornejo et al. (2016) reported that Trichoderma induces root branching and increases shoot biomass as a consequence of cell division, expansion, and differentiation by the presence of fungal auxin-like compounds. This plant growth promotion due to its role in plant hormone production, vitamin production or conversion of materials to a form useful to the plant, nutrient release from soil or organic matter, increased uptake and translocation of minerals in addition inhibited the pathogen through parasitism, predator, antibiosis, competition for space and nutrition as well as by inducing the resistant in plants against pathogens (Suarez et al., 2005).

\section{Conclusions}

These treatments may have a place in the integrated management of Septoria leaf spot on celery, increased its productivity and consequently, reduced the fungicides used. These treatments may not result in the development of resistance in the pathogens.

\section{References}

Abbasi, P.A.; Cuppels, D.A. and Lazarovits, G. 2003. Effect of foliar applications of neem oil and fish emulsion on bacterial spot and yield of tomatoes and peppers. Can. J. Plant Pathol., 25: 41-48.

Akhtar, M. 1999. Plant growth and nematode dynamics in response to soil amendments with neem products, urea and compost. Bioresource Technology, 69: 181-183.

Amein, T.; Wright, S.A.I.; Wikström, M.; Koch, E.; Schmitt, A.; Stephan, D.; Jahn, M.; Tinivella, F.; Gullino, M.L.; Forsberg, G.; Werner, S.; van der Wolf, J. and Groot, 
S.P.C. 2011. Evaluation of non-chemical seed treatment methods for control of Alternaria brassicicola on cabbage seeds. J. Plant Dis. Prot., 118(6): 214-221.

Amutharaj, P.; Sekar, C. and Esath natheer, S. 2013. Development and use of different formulations of Pseudomonas fluorescens siderophore for the enhancement of plant growth and induction of systemic resistance against Pyricularia oryzae in lowland rice. International Journal of Pharma and Bio Sciences, 4(2b): 831-838.

Anonymous, 2000. Internationale Vorschriften für die Prüfung von Saatgut 1999. Seed Science and Technology 27, Supplement, 357 p.

Azoz, Samah N.; El-Taher, A.M.; Boghdady, M.S. and Nassar. Dalia M.A. 2016. The impact of foliar spray with ascorbic acid on growth, productivity, anatomical structure and biochemical constituents of volatile and fixed oils of basil plant (Ocimum basilicum L.). Middle East J. Agric. Res., 5(4): 549-565.

Begum, J.; Anwar, M.N.; Akhter, N.; Nazrul Islam Bhuiyan, M.D. and Hoque, M.N. 2010. Efficacy of essential oils as jute seed protectant. Chittagong Univ. J. Biol. Sci., 5(1 \& 2): 1-7.

Conklin, P. 2001. Recent advances in the role and biosynthesis of ascorbic acid in plants. Plant, Cell and Environ., 24: 383-394.

Contreras-Cornejo, H.A.; Macías-Rodríguez, L.; del-Val, E. and Larsen, J. 2016. Ecological functions of Trichoderma spp. and their secondary metabolites in the rhizosphere: interactions with plants. FEMS Microbiology Ecology, 92(4): 1-17.

Darandeh, N. and Hadavi, E. 2012. Effect of pre-harvest foliar application of citric acid and malic acid on chlorophyll content and post-harvest vase life of Lilium cv. Brunello. Frontiers in Plant Sci., 2: 1-3.

Du Toit, L.J. 2004. Management of diseases in seed crops, in Encyclopedia of Plant and Crop Science, ed. by Goodman R. Marcel Dekker, New York, NY, pp. 675-677.

Elad Y.; Chet, I. and Henis, Y. 1981. A selective medium for improving quantitative isolation of Trichoderma spp. from soil. Phytoparasitica, 9: 59-67.

Elekhtyar, Nehal M. 2015 Efficiency of Pseudomonas fluorescens as plant growthpromoting rhizobacteria (PGPR) for the enhancement of seedling vigor, nitrogen uptake, yield and its attributes of rice (Oryza sativa L.). Int. J. Sci. Res. Agric. Sci., 2(Proceedings), pp. 57-67.

El-Mohamedy, R.S.R. and Abd-El-latif, Faten M. 2015. Field application of humic acid and thyme essential oil for controlling late blight disease of tomato plants under field conditions. Asian J. Plant Pathol., 9 (4): 167-174

El-Mougy, Nehal S. 2009. Effect of some essential oils for limiting early blight (Alternaria solani) development in potato field. J. Plant Prot. Res., 49: 57-62.

Egypt. J. Phytopathol., Vol. 46, No. 2 (2018) 
El-Sharkawy, H.H.A.; Tohamey, S. and Khalil, A.A. 2015. Combined effects of Streptomyces viridosporus and Trichoderma harzianum on controlling wheat leaf rust caused by Puccinia triticina. Plant Pathol. J.. 14(4): 182-188.

El-Sayed, H.A.E. 2013. Exogenous application of ascorbic acid for improve germination, growth, water relations, organic and inorganic components in tomato (Lycopersicon esculentum Mill) plant under salt-stress. New York Sci. J., 6(10): 123-139.

Esterbaner, H.; Schwarzl, E. and Hayn, M. 1977. A rapid assay for catechol oxidase and laccase using 2-nitro-5-thio benzoic acid. Anal. Biochem., 77: 486-494.

Farahani, S.M. and Chaichi, M.R. 2012. Effects of field treatments on barley seed sensitivity to organic seed sanitation (hot water). Res. J. seed Sci., 5(3): 96-105.

Guenther, E. 1961. "The Essential Oils". D. Van Norstand Inc. NY, USA. Pp 569.

Haggag, Wafaa M. and Abd El-Khair. H. 2007. Application of some natural compounds for management of potato late and early blights. J. Food Agri. Envi., 5: 157-163.

Harman, G.E.; Petzoldt, R.; Comis, A. and Chen, J. 2004. Interaction between Trichoderma harzianum strain T-22 and maize inbred Mo17 and effects of these interactions on disease caused by Phytium ultimum and Colletotrichum graminicola. Phytopathology, 94: 147-153.

Hilal, A.A. and Ghebrial, Eman W. 2015. Occurrence of late blight (Septoria apiicola Speg.) on celery (Apium graveolens L.) in Egypt. Egypt. J. Phytopathol., 43(1-2): 187-188.

Inouye, S.; Tsuruoka, T.; Watanabe, M.; Takeo, K.; Akao, M.; Nishiyama, Y. and Yamaguchi, H. 2000. Inhibitory effect of essential oils on apical growth of Aspergillus fumigatus by vapour contact. Mycoses, 43: 17-23.

Ismaeil, Faten H.M. and Bakry, K.H.A. 2005. Response of papaya plants to some chemical substances and yeast extract treatments. $3^{\text {rd }}$ Scientific Conference. Prospects of Scientific Research in the area of Modern Agriculture, 129-150.

Jafari, N. and Hadavi, E. 2012a. Growth and essential oil yield of basil (Ocimum basilicum L.) as affected by foliar spray of citric acid and salicylic acid. $Z$. ArzneiGewurzpfl., 17: 80-83

Jafari, N. and Hadavi, E. 2012b. Growth and essential oil yield of dill (Anethum graveolens) as affected by foliar sprays of citric acid and malic acid. Acta Hort., 955: $287-290$.

Kashyap, A.S. 2013. Studies on leaf spot of tomato caused by Septoria lycopersici Speg. M.Sc. Thesis, Faculty of Agriculture, Dharwad University of Agricultural Sciences, Dharwad, India, Pages 1-69. 
Kaushal, S.; Karnwal, A. and Yuvneet, R. 2013. Potential plant growth promoting activity of rhizobacteria Pseudomonas sp in Oryza sativa. J. Nat. Prod. Plant Resour., 3(4): 38-50.

Khalil, Soha E.; Abd El- Aziz, Nahed G. and Abou Leila, Bedour H. 2010. Effect of water stress, ascorbic acid and spraying time on some morphological and biochemical composition of Ocimum basilicum plant. J. Am. Sci., 6(12): 33-44.

Khan, T.A.; Mazid, M. and Mohammad, F. 2011. Role of ascorbic acid against pathogenesis in plants. J. Stress Physiol. Biochem., 7(3): 222-234.

King, E.O.; Ward, M.K. and Raney, D.E. 1954. Two simple media for the demonstration of pyocyanin and fluorescein. J. Lab. Clin. Med., 44: 301-307.

Kinnersley, A.M.; Scott III, T.C.; Yopp, J.H. and Whitten, G.H. 1990. Promotion of plant growth by polymers of lactic acid. Plant Growth Regulation, 9: 137-146.

Lacy, M.L. 1994. Influence of wetness periods on infection of celery by Septoria apiicola and use in timing sprays for control. Plant Dis., 78: 975-979.

Lacy, M.L.; Berger, R.D.; Gilbertson, R.L. and Littlt, E.L. 1996. Current challenges in controlling diseases of celery. Plant Dis., 80(10): 1084-1090.

Lokanadhan, S.; Muthukrishnan, P. and Jeyaraman, S. 2012. Neem products and their agricultural applications. J. Biopest, 5 (Supplementary): 72-76.

Lucy, M.; Reed, E. and Glick, B.R. 2004. Applications of free living plant growthpromoting rhizobacteria. Anton. Leeuw., 86(1): 1-25.

Lewis Ivey, M.L. and Miller, S.A. 2005. Evaluation of hot water seed treatment for the control of bacterial leaf spot and bacterial canker on fresh market and processing tomatoes. Acta Hort., 695: 197-204.

Maksoud, M.A.; Malaka, A.S.; El- Shamma, M.S. and Amera, A.F. 2009. The beneficial effect of biofertilizers and antioxidants on Olive trees under calcareous soil condition. World J. Agri. Sci., 5(3): 350-352.

Mancini, V. and Romanazzi, G. 2014. Seed treatments to control seedborne fungal pathogens of vegetable crops. Pest Manag. Sci., 70: 860-868.

Mathieu, D. and Kushalappa, A.C. 1993. Effects of temperature and leaf wetness duration on the infection of celery by Septoria apiicola. Phytopathology, 83: 10361040.

Miri, S.M.; Ahmadi, S. and Moradi, P. 2015. Influence of salicylic acid and citric acid on the growth, biochemical characteristics and essential oil content of thyme (Thymus vulgaris L.). J. Medicinal Plants and By-products, 2: 141-146. 
Miller, S.A. and Lewis Ivey, M.L. 2005. Hot water and chlorine treatment of vegetable seeds to eradicate bacterial plant pathogens. The Ohio State University Pathology Extension Fact Sheet, Pages 1-5.

Moran, R. 1982. Formula determination of chlorophyllous pigment extracted with N, Ndimethyl farmamide, Plant Physicl., 69:1376-1381.

Mtui, H.D.; Bennett, M.A.; Maerere, A.P.; Miller, S.A.; Kleinhenz, M.D. and Sibuga, K.P. 2010. Effect of seed treatments and mulch on seedborne bacterial pathogens and yield of tomato (Solanum lycopersicum Mill.) in Tanzania. J. Animal \& Plant Sci., 8(3): 1006- 1015.

Muniz, M.F.B. 2001. Control of microganisms associated with tomato seeds using thermotherapy. Revista. Brasileira-sementes., 23 (1): 176-280.

Nahak, G. and Sahu, R.K. 2015. Biopesticidal effect of leaf extract of neem (Azadirachta indica A. Juss) on growth parameters and diseases of tomato. J. Appl. \& Nat. Sci. 7(1): 482-488.

Nzanza, B.; Marais, D. and Soundy, P. 2011. Tomato (Solanum lycopersicum L.) seedling growth and development as influenced by Trichoderma harzianum and arbuscular mycorrhizal fungi. Afr. J. Microbiol. Res., 5(4): 425-431.

Omer, A.K.H. 1999. Response of Red Roomy grapevines to some antioxidants and bio fertilizer treatments. M.Sc. Thesis, Fac. Agric., Minia Univ., Egypt, 1-68.

Pina-Vaz, C.; Goncalves Rodrigues, A.; Pinto, E.; Costa-De-Oliveira, S.; Tavares, C.; Salgueiro, L.; Cavaleiro, C.; Goncalves, M.J. and Martinez-De-Oliveira, J. 2004. Antifungal activity of Thymus oils and their major compounds. J. Eur. Acad. of Dermatol. Venereol., 18: 73-78.

Rasooli, I. and Owlia, P. 2005. Chemoprevention by thyme oils of Aspergillus parasiticus growth and aflatoxin production. Phytochemistry, 66: 2851-2856.

Reda, Fatma; Baroty, G.S.A.; Talaat, I.M.; Abdel-Rahim, I.A. and Ayad, Hasnaa S. 2007. Effect of some growth regulators and vitamins on essential oil, phenolic content and activity of oxidoreductase enzymes of Thymus vulgaris L. World J. Agric. Sci., 3(5): 630-638.

Riccioni, L. and Orzali, L. 2011. Activity of tea tree (Melaleuca alternifolia, Cheel) and thyme (Thymus vulgaris, Linnaeus.) essential oils against some pathogenic seed borne fungi. J. Essential Oil Res., 23: 43-47.

Sánchez, M.E.; Turina, A.V.; García, D.A.; Nolan, M.V. and Perillo, M.A. 2004. Surface activity of thymol: implications for an eventual pharmacological activity. Colloids Surf B. Biointerfaces, 34: 77-86. 
Schmitt, A.; Koch, E.; Stephan, D.; Kromphardt, C.; Jahn, M.; Krauthausen, H.-J.; Forsberg, G.; Werner, S.; Amein, T.; Wright, S.A.I.; Tinivella, F.; van der Wolf J. and Groot, S.P.C. 2009. Evaluation of non-chemical seed treatment methods for the control of Phoma valerianellae on lamb's lettuce seeds. J. Plant Dis. Prot., 116(5): 200-207.

Segvić Klarić, M.; Kosalec, I.; Mastelić, J.; Piecková, E. and Pepeljnak, S. 2007. Antifungal activity of thyme (Thymus vulgaris L.) essential oil and thymol against moulds from damp dwellings. Lett. Appl. Microbiol., 44:36-42.

Sheridan, J.E. 1966. Celery leaf spot: sources of inoculums. Ann. App. Biol., 57(1): 7581.

Snedecor, G.W. and Cochran, W.G. 1989. "Statistical Methods". 8th. ed. Iowa State Univ. Press, Ames, Iowa, USA, 251 pp.

Soltani, Y.; Saffari, V.R. and Moud, A.A.M. 2014. Response of growth, flowering and some biochemical constituents of Calendula officinalis L. to foliar application of salicylic acid, ascorbic acid and thiamine. Ethno-Pharmaceutical Products., 1(1): 37-44.

Soylu, E.M.; Soylu, S. and Kurt, S. 2006. Antimicrobial activities of the essential oils of various plants against tomato late blight disease agent Phytophthora infestans. Mycopathologia, 161: 119-128.

Suarez, M.B.; Sanz, L.; Luis, S.; Isabel Chamorro, M.; Rey, M.; Gonzalez, F.J.; Llobell, A. and Monte, E. 2005. Proteomic analysis of secreted proteins from Trichoderma harzianum: Identification of a fungal cell wall-induced aspartic protease. Fungal Gen. Biol., 42: 924-934.

Wassel, A.H.; Hameed, M.A.; Gobara, A. and Attia, M. 2007. Effect of some micronutrients, gibberellic acid and ascorbic acid on growth, yield and quality of white Banaty seedless grapevines. African Crop Sci. Conference Proceeding, 8: 547-553.

Worthington, x.x. 1971. "Enzyme Manual", Worthington Biochemical Corp., Freehold, New Jersey, Pages 41-45.

Xue, A.G.; Guo, W.; Chen, Y.; Siddiqui, I.; Marchand, G.; Liu, J. and Ren, R. 2017. Effect of seed treatment with novel strains of Trichoderma spp. on establishment and yield of spring wheat. Crop Prot., 96: 97-102.

Yadav, B.; Singh, R. and Kumar, A. 2015. Management of spot blotch of wheat using fungicides, bio-agents and botanicals. African J. Agric. Res. 10(25): 2494-2500.

Yan, Z.; Reddy, M.S.; Ryu, C.M.; McInroy, J.A.; Wilson, M. and Kloepper, J.W. 2002. Induced systemic protection against tomato late blight elicited by plant growthpromoting rhizobacteria. Phytopathology, 92: 1329-1333.

(Received 01/08/2018;

in revised form 12/09/2018) 
استخدام بعض بدائل المبيدات لمكافحة التبقع السبتورى لأوراق الكرفس وتحسين انتاجيته ايمان وجيه راغب غبريال ، ،و عادل جلال محمود قناوى 2

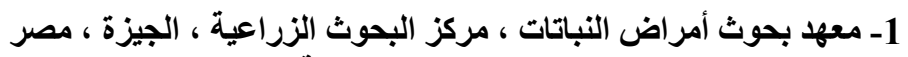

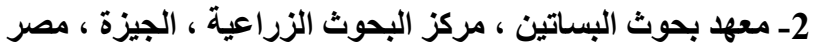

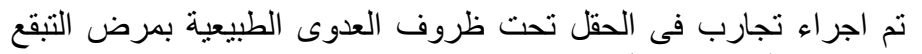

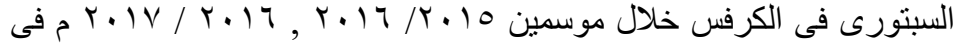

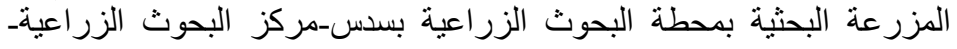

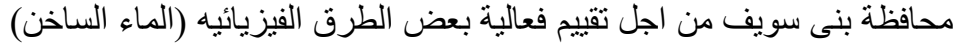

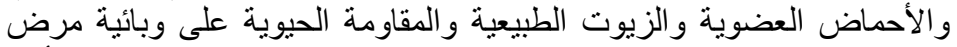

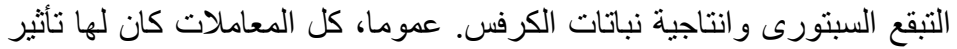

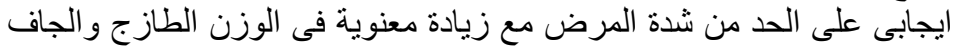

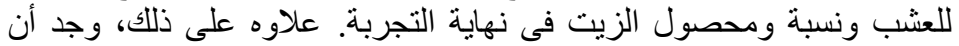

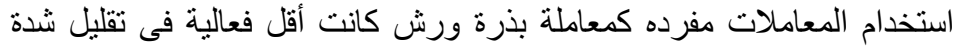

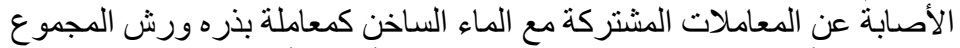

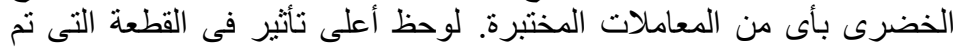

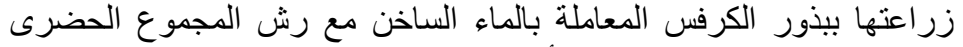

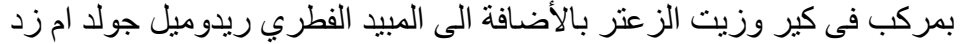

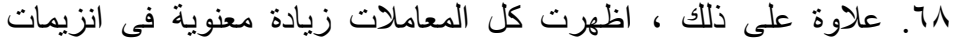

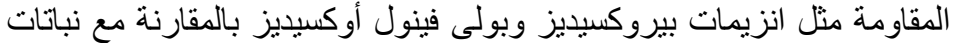
الكرفس الغير معاملة. 